This manuscript is an author-supplied post-print created for green open access repository deposit. For citation, please endeavor to consult the published version of record:

Jackson, Jason Baird. "At Home and Abroad: Reflections on Collaborative Museum Ethnography at the Mathers Museum of World Cultures." Museum Anthropology 42, no. 2 (2019): 62-70. https://doi.org/10.1111/muan.12210.

\title{
At Home and Abroad: Reflections on Collaborative Museum Ethnography at the Mathers Museum of World Cultures
}

Jason Baird Jackson

Indiana University

\section{Abstract}

In a reflective essay, the author draws upon experiences in two ongoing projects to suggest ways in which the literatures on museum-based ethnographic collaboration might be enriched and extended. One illustrative project is a binational, multiinstitutional endeavor linking six museums within a larger program of cooperation led by two national scholarly societies. The other case is the work of an ethnographically-oriented, museum-based public arts program working on a statewide basis in a midwestern state in the United States. The author concludes with a call to develop frameworks for fostering partnership activities between museums of ethnography.

\section{Keywords}

Anthropological Museums; Ethnological Museums; Cooperation; Ethnography; International Cooperation

\section{Introduction}

In this reflective essay, my aim is to characterize two key projects of the Mathers Museum of World CulturesIndiana University's (IU) museum of ethnography, ethnology, 
and cultural history (Jackson 2015, 2016). I will describe the Mathers' recent work among the minority nationalities of Southwest China and, closer to home, with artists and tradition bearers around the state of Indiana. It is my hope that brief consideration of these cases can help further pluralize a literature on museum collaboration based heavily on ethnographically-focused projects pursued in Native North American contexts (The relevant literature is now large. Representative works include: Ames 1990, 1999; Christen 2007; Hertz 2017; Jackson 1990; Lassiter 2005; Lassiter et al. 2004; McMullen 2008; Swan and Jordan $2015) \cdot{ }^{1}$

\section{Southwest China}

In 2007, the American Folklore Society and the China Folklore Society, along with various Chinese and American institutions, embarked upon a program of binational scholarly collaboration. Four years of preliminary discussion and exchange moved to a more formal level in 2011, when the Henry Luce Foundation and a number of other Chinese and American funders supported a two-year project exploring and comparing folklore scholarship and intangible cultural heritage (ICH) policy and practice in the two nations. The center of gravity for this phase of work was 
four binational conferences and a program of exchange that enabled younger scholars to travel and become acquainted with method, theory, and professional practice in their respective host nations. The exchange participants traveling from China to the United States were, by design, not Americanists and those Americans traveling to China were not specialists in China. Such specialists did participate in important ways in the programs of conferences initiated during this period. (Lloyd 2017; Dewhurst and Lloyd 2019; MacDowell and Zhang, eds. 2016; Zhang and Song, eds. 2017).

As this project moved toward conclusion in 2012, plans developed for further work. A key focus in this next phase was exploring ethnographic museums as sites for ICH initiatives. Within the larger AFS-CFS partnership, a subproject was developed that would link six museums-three from China and three from the U.S. At about the same moment that it became known that I would be named Mathers' director, I was asked if the museum would like to become one of the three U.S. partners. I jumped at this chance, as it articulated closely with both my goals for the museum and the international priorities of our campus (American Folklore Society 2018; Indiana University 2013, 2014). 
The Luce Foundation generously agreed to support this next phase of work, being joined over time by additional funders (Lloyd 2017). With three new years of Luce support, the Mathers joined Santa Fe's Museum of International Folk Art (MoIFA) and the Michigan State University (MSU) Museum on the U.S. side of the project. Aiming to use the strategies for international collaborative partnerships described by Kurt Dewhurst and Marsha MacDowell in a contribution (2015) to Practicing Anthropology, the MSU Museum co-led the effort with the Yunnan Nationalities Museum, with which it had already established ties. Whereas Dewhurst and MacDowell, as MSUM's project leaders, invited Mathers and MoIFA to the effort, Xie Mohua, then-director in Yunnan invited two peer institutions among the provincial nationalities museums in China's Southwest-the Guizhou Nationalities Museum and the Anthropology Museum of Guangxi ( Figure 1)

Between 2013 and 2016, the partners pursued several tasks. As with the earlier phase of Luce-funded work, professional exchanges were prioritized as were binational conferences. Two more were held-one hosted by the Guizhou Nationalities Museum in Guiyang and one hosted by MoIFA in Santa Fe (Figure 2) (American Folklore Society and Museum of International Folk Art 2014; China Folklore Society and the Guizhou Nationalities Museum 2015; American Folklore Society 2018). The binational project 
team also pursued a jointly curated exhibition, which was devised as a proof-of-concept effort that would teach us about exhibition development strategies operating in both national museum communities. That work resulted in the bilingual traveling show Quilts of Southwest China as well as a bilingual catalog (Figures 3-4) (MacDowell and Zhang, eds. 2016; Hertz 2017a).2 As AFS Executive Director emeritus Tim Lloyd (2017) has described, a wide range of unexpected benefits also emerged from our work, including spin-off exhibitions, new publications, and the building of well-documented museum collections. ${ }^{3}$

Given that the Quilts of Southwest China exhibition is an ethnographic representation exploring cultural life among the minority nationalities of China's Southwest, did we engage in field research? If so, was that research recognizable as collaborative in some sense stressed in the Anglophone museum anthropology or museum-based folklore studies literatures? I will take up those questions below, but first want to open my other story.

\section{Traditional Arts Indiana}

Jon Kay, as Director of Traditional Arts Indiana (TAI), has written elsewhere about TAI's recent work (Kay 2016c, 2019). Here I will situate its place at the museum just enough to allow me to evoke it in the context of the 
collaboration literature. For reasons of space and focus, I am omitting an interesting story of how, in 2015,

Traditional Arts Indiana unexpectedly became a constituent program of the Mathers Museum (Indiana University 2015). For my purpose here, it is enough to know that TAI is now based at the Mathers and that it remains Indiana's official folk and traditional arts program (Mathers Museum of World Cultures 2018). With support from IU, the Indiana Arts Commission, and the National Endowment from the Arts, it undertakes research on the diverse arts and traditional cultural expressions found in the state, trains students for public folklore careers, develops podcasts and other media, hosts demonstrations and events around the state, provides skills training to artists and culture workers, presents exhibitions, arranges master-apprentice programs, publishes accessible scholarship, and generally fosters the state's cultural diversity (Kay 2016b, 2016c. 2019). In its second decade as a collaboration between state government and Indiana University, TAI is Indiana's official traditional arts support and development program, with its director filling the role of state folklorist that is found in most U.S. states (Figure 5).

\section{Museum Collaborations}


Does our work in China and Indiana fit under the collaborative anthropology banner? I think so, but both cases differ from the paradigmatic instance of museumcommunity collaboration in Native American communities in which I was socialized and have worked (Jackson 1990; Swan and Jordan 2015)

In China, research-from the vantage point of the American museum participants-was extremely rudimentary. As non-specialists in the ethnography of China, time spent with our colleagues sensitized us to the basic circumstances of both Chinese museum practice and-through brief fieldtrips led by our Chinese hosts-to the lived experiences of minority communities in China's Southwestparticularly among groups at the leading edge of heritage tourism activity. 4 The same dynamic occurred in reverse when we introduced our Chinese colleagues to individuals and groups in New Mexico, Michigan, or Indiana. As in China, our American interlocutors are known to us through in-depth specialist research and substantive partnerships, much of it paradigmatically collaborative, but our Chinese colleagues gained (as we did in China) only preliminary insights in a mediated way. I am arguing that this is far better than nothing. In some cases, it may be the beginning and the end. In others it may be the basis for more 
sustained and robust collaborative research work (Figures $6-7) \cdot$

Our Chinese colleagues are engaged in complex, longterm research endeavors as specialists with high levels of knowledge concerning the peoples of their regions, including their languages, cultures, histories, and socioeconomic circumstances. This is true for the work that the American participants are pursuing in their states as well. One kind of collaboration, in this case between the U.S. and Chinese museums, is leveraging another kind of more local collaboration-between the museums and various individuals, groups, institutions, and polities that are networked into ongoing museum efforts. While one of the U.S. museums could theoretically hire a specialist curator prepared to pursue independent research in Southwest Chinathis is highly unlikely. Instead, we have collaborations networked into other collaborations.

The paradigmatic Native American community based-model of collaborative museum work is predicated on an engageable collective-a tribal council, a tribal museum, a cultural organization, or other group prepared to stand as an organization-to-organization partner (Swan and Jordan 2015; McMullen 2008). We see this model extended in public folklore partnerships in which a research and presenting 
organization partners with an immigrant advocacy group, a culturally-specific religious congregation, or an urban ethnic association (Hertz 2017). Whereas the institutional complexities in China are more complex than this model can accommodate, the work of Traditional Arts Indiana suggests too that this model can also be too complex for a more elementary, individual-centric social reality.

In the TAI case, the artists, craftspeople, musicians, and other tradition bearers with which TAI works are rarely represented by formal groups in a manner analogous to my experiences in Indian Country. They are also representative of cultural groups in a much more diffuse manner. Willow basket maker Viki Graber of Goshen, Indiana, for example, feels rooted in her Mennonite heritage and in her multigenerational family basket making tradition, but she is not represented by a tribal council-like group and she does not speak on behalf of, or even stand as an unambiguous representative of, a classically conceived "community." She is socially networked complexly and she engages with a range of occupational, affiliational, place-based, and virtual social groupings, but the canonical group-based approach to collaboration would be an awkward fit for our museum's work with her and with most other artisans and craftspeople with whom TAI works.5 (Figure 8) 
The Chinese case offers a different model-one in which a museum benefits from partnering-one might say coattailing-with other institutional partners, with partners who are better positioned to sustain the kinds of extended collaborations that are at the heart of our literatures. As Dewhurt and MacDowell $(2016,54)$ note though, an institution that is coat-tailing on one front (as the Mathers Museum is vis-à-vis local knowledge and relationships in Southwest China) has to bring something else to the table to make institutional partnerships reciprocal and thus successful.

The work that the Mathers Museum of World Cultures is pursuing through Traditional Arts Indiana tweaks the museum collaboration literature in a different way. In the TAI case, geographically or topically-focused survey work leads to the discovery of craftspeople and other individual tradition bearers (Kay 2016b, 2016c, 2019). Under norms of individual autonomy but not necessarily fine art world-style individualism, these creative and culture-minded individuals enter (or do not enter) into collaborations that are largely organization-to-individual in structure.

In "Contingent Collaborations: Patterns of Reciprocity in Museum-Community Partnerships, Daniel C. Swan and Michael Jordan (2015) updated and extended what I think of as the classic 
collaboration framework at work in museum ethnography projects. Building on work by Kim Christen (2007) and others, as well as their own first-hand experiences, they stress the contingent intersection of local and institutional interests, the reciprocal obligations that arise in institution-to-community group partnerships, and the challenges of sustaining, and of not-sustaining, partnerships given the divergent needs of all parties as well as the different time horizons characterizing the engagements of museums and community groups. I embrace and celebrate the standard model as extended by Swan and Jordan and discussed regularly by many other leaders in museum anthropology and museum folklore.

My closing reflection here though points to our need to further develop an equally robust literature relating to museum collaborations that are in various ways sub-communal but still fundamentally about culture, society, and history in the anthropological sense rather than idiosyncratic creativity and personality in the sense dominant in art museum contexts. With the experience of decades of public sector folklore work at their disposal, folklorists are probably in the lead on this front (Hertz 2017b; Dewhurst 2017; Dewhurst, Hall, and Seeman, eds. 2017). While TAI's work is a part of that story, the work of the Mathers and its partners in China points to a need to map and more fully assess larger-scale, networked, multi- 
institutional collaborations (or collaborations of collaborations) (Dewhurst and MacDowell 2015; Dewhurst and Lloyd 2019; Laely 2018; Otto 2019). Of value in this continued work will be new scholarship that is trying to make ethnographic sense of broader interdisciplinary research practices in the era of "grand challenges" and related high stakes interdisciplinary endeavors (Bendix, Bizer, and Noyes 2017).

My interest here is practical, as our museum partnership in China received additional funding from the Luce Foundation (American Folklore Society 2017). Combined with investments from the Anthropology Museum of Guangxi, this funding has allowed us to pursue new research in Northern Guangxi through at least 2019. In this work, we have shifted from the working tourism that characterized our earlier orienting visits to more robust ethnographic field research on local textile practices that is collaborative on the institutional plane and on the institutionto-local groups and individuals plane. Essential to this new work are two additional partners-the Nandan Baiku Yao Eco-Museum and the Sanjiang Dong Eco-Museum, both local level, community based ethnographic museums. (Preliminary reflections on our fieldwork appear in Jackson 2018a; Hertz 2018; Kay 2018; Liang 2018 and related blog posts). The established literatures on collaboration in anthropology and folklore studies definitely help us, but they do not provide a certain roadmap. ${ }^{6}$ I look 
forward to sharing more of what our multi-institutional, binational team learns about how best to pursue such work in the years ahead (Jackson 2018b; American Folklore Society and Mathers Museum of World Cultures 2019). (Figures 9-10)

Based on our work since 2013, including a range of collaborations in exhibition, publishing, collections development, and research, I would like to close with a possible action item for the university museum anthropology community to consider. Given the special institutional circumstances that we share and the benefits that could flow from more durable institution-level partnerships, I advocate exploring the formation of a network or organization linking campus museums with anthropology/ethnography programs. Such a network could provide a context for information sharing and the fostering of specific collaborations, including the sorts of exhibition exchanges that the Mathers Museum and its partners have been engaging in. It could also, for instance, provide a context for advocacy on behalf of our part of the field. The early history of the Association of Art Museum Directors (2018) might provide an inspirational comparative case. For other goals that our community might consider, I close by highlighting the 2015 white paper issued by the Folklore and Public Policy Working Group on Folklore and Museums (Bol, et al. 2015), a group convened by the American Folklore Society to advance the collective work of 
museum-based folklore studies. In framing its recommendations, the working group particularly highlighted the ways that museumbased folklorists could cooperate with the Council for Museum Anthropology and the wider museum anthropology community in pursuit of what were seen as shared interests and goals.

\section{References Cited}

American Folklore Society. 2017. “AFS Receives Henry Luce Foundation Funding to Continue US-China Collaborations." February 17, 2017 .

https://www.afsnet.org/news/news.asp?id=331685

- 2018. "China-US Folklore and Intangible Cultural Heritage Project." Accessed August 16, 2018

https: //Www.afsnet.org/page/FICH

- and Mathers Museum of World Cultures. 2019. The Seventh Forum on China-US Folklore and Intangible Cultural Heritage: Collaborative Work in Museum Folklore and Heritage Studies. Beijing: Mathers Museum of World Cultures, Indiana University. and Museum of International Folk Art. 2014. The Fifth Forum on China-US Folklore and Intangible Cultural Heritage: Bridging Tangible and Intangible Cultural Heritage in Ethnographic Museums and Heritage Sites. Santa Fe: Museum of International Folk Art. 
https://cdn.ymaws.com/www.afsnet.org/resource/resmgr/Docs/N ovember 2014 Museum Confere.pdf

Ames, Michael M. 1990. “Cultural Empowerment and Museums: Opening Up Anthropology through Collaboration." In Objects of Knowledge, edited by Susan Pearce, 158-73. London: Athlone Press.

—. 1999. "How to Decorate a House: The Re-Negotiation of Cultural Representations at the University of British Columbia Museum of Anthropology." Museum Anthropology 22 (3) : 41-51. https://doi.org/10.1525/mua.1999.22.3.41 Association of Art Museum Directors. 2018. "Our History." Accessed August 16, 2018. https://aamd.org/about/mission Bendix, Regina, Kilian Bizer, and Dorothy Noyes. 2017. Sustaining Interdisciplinary Collaboration: A Guide for the Academy. Urbana: University of Illinois Press.

Bol, Marsha, C. Kurt Dewhurst, Carrie Hertz, Jason Baird Jackson, Marsha MacDowell, Charlie Seemann, Suzy Seriff, and Daniel Sheehy. 2015. Rethinking the Role of Folklore in Museums: Exploring New Directors for Folklore in Museum Policy and Practice. Bloomington, IN: American Folklore Society. https://afsnet.site$\mathrm{ym} . \mathrm{com} /$ resource/resmgr/Folklore and Museum Policy a.pdf China Folklore Society and the Guizhou Nationalities Museum. 2015. China-US Nationalities Museums Cooperative Project 
Forum. Guiyang: Guizhou Nationalities Museum.

https : //cdn.ymaws.com/www.afsnet.org/resource/resmgr/Docs/A pril 2015 Museum Conference.pdf

Chio, Jenny. 2014. A Landscape of Travel: The Work of Tourism in Rural Ethnic China. Seattle: University of Washington Press.

Christen, Kimberly. 2007. "Following the Nyinkka: Relations of Respect and Obligations to Act in the Collaborative Work of Aboriginal Cultural Centers." Museum Anthropology 30 (2): 101-24. https://doi.org/10.1525/mua.2007.30.2.101

Dewhurst, C. Kurt. 2017. "Folklife and Museum Practice." In Folklife and Museums: Twenty-First-Century Perspectives, edited by C. Kurt Dewhurst, Patricia Hall, and Charlie Seemann, 1-26. Landham, MD: Rowman and Littlefield.

-., Patricia Hall, and Charlie Seemann, eds. Folklife and Museums: Twenty-First-Century Perspectives. Landham, MD: Rowman and Littlefield.

- and Marsha MacDowel1. 2015. "Strategies for Creating and Sustaining Museum-Based International Collaborative Partnerships." Practicing Anthropology 37 (3): 54-55. https://doi.org/10.17730/0888-4552-37.3.54

- and Timothy Lloyd. 2019. “The American Folklore SocietyChina Folklore Society Folklore and Intangible Cultural 
Heritage Project, 2013-2016." Museum Anthropology Review. 13 (1) : 59-68. https://doi.org/10.14434/mar.v13i1.25405

Hertz, Carrie. 2017a. "Picturing the Future: Quilts of Southwest China." El Palacio 122 (2): 88-91.

—. 2017b. "Public Folklore Curatorship." In Folklife and Museums: Twenty-First-Century Perspectives, edited by C. Kurt Dewhurst, Patricia Hall, and Charlie Seemann, 319-48. Landham, MD: Rowman and Littlefield.

—. 2018. "Fieldwork: Highlights from the Textile Group." Shreds and Patches. March 17, 2018. https://jasonbairdjackson.com/2018/03/17/fieldworkhighlights-from-the-textile-group/

Indiana University. 2013. “IU'S Mathers Museum One of Three U.S. Institutions to Collaborate with Chinese Museums." November $19,2013$.

http://archive.news.indiana.edu/releases/iu/2013/11/mathers -museum-collaboration.shtml

-. 2014. "Indiana University Opens Office in Beijing, Signs Agreements with Three Top Chinese Universities." May 23, 2014. http://archive.news.iu.edu/releases/iu/2014/05/iuconcludes-china-trip-by-opening-new-office.shtml

—. 2015. "Traditional Arts Indiana Thriving in New Home at IU's Mathers Museum." March 12, 2015. 
http://archive.news.indiana.edu/releases/iu/2015/03/traditi onal-arts-indiana-mathers.shtml

Jackson, Jason Baird. 2000. "Ethnography and Ethnographers in Museum-Community Partnerships." Practicing Anthropology 22 (4) : 29-32. https://doi.org/10.17730/praa.22.4.3013vn01482324x4

—. 2015. "Interconnections: Folklore Studies and Anthropology at the Mathers Museum of World Cultures." Practicing Anthropology 37 (3): 20-23. https://doi.org/10.17730/0888$\underline{4552-37.3 .20}$

—. 2016. “Mathers Museum of World Cultures." In 中国西南拼布 | Quilts of Southwest China, edited by Marsha MacDowell and Lijun zhang, 69-72. Nanning: Guangxi Museum of Nationalities.

-. 2018a. "Fieldwork: Highlights from the Basketry and Architecture Group." Shreds and Patches. February 13, 2018. https://jasonbairdjackson.com/2018/02/13/fieldworkhighlights-from-the-basketry-and-architecture-group/

—. 2018b. "Lessons from a Partnership Linking a Network of Chinese and American Museums of Ethnography." Paper presented in the session "Cooperation and Partnership" at the International Committee of Museums of Ethnography Meetings, Estonian National Museum, Tartu, Estonia. 
Kay, Jon, 2016a. Folk Art and Aging: Life-Story Objects and their Makers. Bloomington: Indiana University Press. https://scholarworks.iu.edu/dspace/handle/2022/20906

-., ed. 2016b. Indiana Folk Arts: 200 Years of Tradition and Innovation. Bloomington: Mathers Museum of World Cultures. http://hdl.handle.net/2022/20893

—. 2016c. "Traditional Arts Indiana at Indiana University's Mathers Museum." Journal of Folklore and Education 3: 10912. https://scholarworks.iu.edu/dspace/handle/2022/20993.

- 2018. "The Mallet: Making a Maul in a Baiku Yao Community." Shreds and Patches. April 19, 2018.

https://jasonbairdjackson.com/2018/04/19/the-mallet-makinga-maul-in-a-baiku-yao-community/

- 2019. “Traditional Arts Indiana's Bicentennial Exhibition. Museum Anthropology Review 13 (1): 11-31. https://doi.org/10.14434/mar.v13i1.24990

Laely, Thomas. 2018. "Why Do African and European Museums Cooperate? Reimagining a Paradigm of Knowledge Production and Partnership." Paper presented in the session "Cooperation and Partnership" at the International Committee of Museums of Ethnography Meetings, Estonian National Museum, Tartu, Estonia.

Lassiter, Luke E. 1998. The Power of Kiowa Song: A Collaborative Ethnography. Tucson: University of Arizona Press. 
- 2005. The Chicago Guide to Collaborative Ethnography. Chicago Guides to Writing, Editing, and Publishing. Chicago: University of Chicago Press.

-., Hurley Goodall, Elizabeth Campbell, and Michelle Natasya Johnson. 2004. The Other Side of Middletown: Exploring Muncie's African American Community. Walnut Creek, $\triangle \mathrm{CA}$ : AltaMira Press.

Liang Xiaoyan.2018 . 侗绣馆的“自我表演”：2018中美合作三江民间纺织品调研 拍摄手记 (三). Accessed August 16，2018. https://mp.weixin.qg.com/s/P5MKRJJ1Fl8f1wTFdmZRVQ Lloyd, Timothy. 2017. "The Inside Story of the AFS China-US Project." June 12, 2017. http://www.afsnet.org/news/349609/The-Inside-Story-of-theAFS-China-US-Project.htm.

MacDowell，Marsha，and Lijun Zhang，eds. 2016. 中国西南拼布 | Quilts of Southwest China. Nanning: Guangxi Museum of Nationalities. [Distributed in the United States by Indiana University Press.]

Mathers Museum of World Cultures. 2018. “Traditional Arts Indiana." Accessed August 16, 2018. https://mathersmuseum.indiana.edu/traditional-artsindiana.html

McMullen, Ann. 2008. "The Currency of Consultation and Collaboration." Museum Anthropology Review 2(2): 54-87. 
https://scholarworks.iu.edu/journals/index.php/mar/article/ view/88

Noyes, Dorothy. 2016. Humble Theory: Folklore's Grasp on Social Life. Bloomington: Indiana University Press.

Otto, Kristin. 2019. “Negotiating Museum Practice Through Collections-Based Collaboration: Examples from Museums in Africa and the West." Paper presented at The Seventh Forum on China-US Folklore and Intangible Cultural Heritage: Collaborative Work in Museum Folklore and Heritage Studies. Indiana University China Gateway, Beijing, China.

Swan, Daniel C., and Michael Paul Jordan. 2015. "Contingent Collaborations: Patterns of Reciprocity in Museum-Community Partnerships." Journal of Folklore Research 52 (1): 39-84. https://doi.org/10.2979/jfolkrese.52.1.39

Watson, Carolisa. 2016. "Viki Graber, Willow Basketweaver." In Indiana Folk Arts: 200 Years of Tradition and Innovation, edited by Jon Kay, 50-51. Bloomington, IN: Mathers Museum of World Cultures. http://hdl.handle.net/2022/20893

Zhang, Juwen and Song Junhua, eds. 2017. Metafolklore: Stories of Sino-US Folkloristic Cooperation | 文化对话: 中美非物质文化遗 产论坛. Guangzhou: Sun Yat-sen University Press.

Zhang, Lijun and Jason Baird Jackson. 2018. “Common Instruments: Putting Baskets to Work in Southwest China." Hand/Eye. June 
20, 2018. http://handeyemagazine.com/content/common-

instruments

\section{Figures}

Figure 1. Representatives of the six partner museums at the first project meeting, hosted by the Yunnan Nationalities Museum in Kunming, Yunnan, China. December 9, 2013. Photograph courtesy of the Yunnan Nationalities Museum.

Figure 2. North American and Chinese participants in The Fifth Forum on China-US Folklore and Intangible Cultural Heritage, an event organized by project participants from the American Folklore Society and the China Folklore Society around the theme "Bridging Tangible and Intangible Cultural Heritage in Ethnographic Museums and Heritage Sites" and hosted by the Museum of International Folk Art in Santa Fe, New Mexico, USA. November 10-11, 2014 Photograph courtesy of the Museum of International Folk Art.

Figure 3. Student performers help open the Quilts of Southwest China exhibition at Michigan State University Museum, East Lansing, Michigan, USA. September 27, 2015. Photograph by the author.

Figure 4. A gallery shot of the Quilts of Southwest China exhibition as presented at the Museum of International Folk 
Art (July 9, 2017-January 21, 2018), Santa Fe, New Mexico, USA. Photograph by Blair Clark and courtesy of the Museum of International Folk Art.

Figure 5. Hooked rug maker Marian Sykes and her work, which have been the focus of TAI/Mathers Museum of World Cultures research, exhibitions, and programs as well as Jon॰Kay's book Folk Art and Aging (2016a). Chesterton, Indiana, USA. Photograph courtesy of Jon Kay.

Figure 6. In the early phase of our cooperative work-both in China and the U.S.-our first encounters with local cultural life in a region sometimes followed well-trodden cultural tourism pathways. Such visits helped us learn about the local impacts of cultural heritage policy. Welcoming rituals for visiting tour groups have become ubiquitous in Southwest China. Here our group is about to be welcomed to the oldest (1998) of the region's eco-museum communities, the Liuzhi Suojia Miao Ecomuseum in Guizhou. April 16, 2015. Photograph by the author.

Figure 7. Project participants from the United States and China learn about Northern Rio Grande weaving from Irvin Trujillo at Centinela Traditional Arts near Chimiyo, New Mexico, November 9, 2014. Photograph by the author.

Figure 8. Willow basketmaker Viki Graber at work during a TAIorganized demonstration at the Fiber Arts Weekend, Spring 
Mill State Park, near Mitchell, Indiana, USA. September 3, 2016. Photograph from the Traditional Arts Indiana Collection, Mathers Museum of World Cultures.

Figure 9. Jon Kay (left) of the Mathers Museum of World Cultures documents Li Guicai (center) of Huaili village (Nandan County, China) making a bamboo basket of a type used among the Baiku Yao for gifts of sticky rice. In the background, Wang Yucheng of the Anthropological Museum of Guangxi documents the fieldwork process and the work of an ethnographic research team that includes staff from the Nandan Baiku Yao Ecomuseum, the Michigan State University Museum, the Anthropological Museum of Guangxi, and the Mathers Museum of World Cultures. December 15, 2017. Photograph by the author.

Figure 10. Yang Tian displays a dragon papercut that she has just made during a demonstration for the visiting research team. She and other Dong artists use such papercuts as patterns to produce the kinds of embroidery designs seen here in her own clothing. Tongle (Sanjiang County, China). July 17, 2018. Photograph by the author. 


\section{Notes}

1 This paper was original presented at the 2017 American Anthropological Association's annual meeting in an Executive Session titled "Looking Ahead: University Anthropology Museums Matter" organized by the author and supported by the Council for Museum Anthropology. Appreciation is extended to the other university museum directors participating in that panel and for the thoughtful comments shared by attendees to that session and by peer-reviewers of this manuscript. Thanks go as well to the editorial staff of Museum Anthropology.

2 On July 15, 2018 the exhibition that toured the U.S. under the title Quilts of Southwest China opened a new Chinese tour at the Anthropology Museum of Guangxi with a new title: Quilting Arts and Tradition: People, Handicrafts, and Community Life. Having been presented in the U.S. at all three partner museums, plus at the International Quilt Study Center and Museum at the University of Nebraska, Lincoln, the exhibition has now also traveled in China to all three Chinese partners museums. It has continued on to additional regional museums in Guangxi. 3 So far, the other exhibitions derived from the project are Beijing's 798 Art Zone (co-curated by Jason Baird Jackson and Wenhong Luo) presented at the Mathers Museum of World Cultures (April 6 to December 12, 2017) and Putting Baskets to Work in Southwest China (co-curated by Lijun Zhang and Jason Baird 
Jackson) presented first at the Mathers Museum of World Cultures (September 1, 2015 to February 7, 2016) and then at the Sam Noble Oklahoma Museum of Natural History (June 9 to August 12, 2018) For the basketry exhibition, see Zhang and Jackson 2018). 4 An accounting of our group travels in Yunnan, Guizhou, Guangxi, Indiana, New Mexico, and Michigan is beyond the scope of this essay, but some sense of the kinds of communities that we visited in Southwest China is available in Jenny Chio's (2014) ethnography of heritage tourism in that region. While we did not visit the specific communities that she chronicles, the places that we visited and the peoples whom we met share much with those that are the focus of her sustained ethnographic work. ${ }^{5}$ For background on Graber, see Watson 2016. For other individual TAI collaborators, see Kay, ed. 2016. For the complexity of notions of community and network relevant to this discussion, see Noyes 2016, 17-94).

${ }^{6}$ A reviewer of this contribution to Museum Anthropology suggested that developing generalizable road maps for museum collaborations would be useful. It may be that in future reflections on our work with partners in China and Indiana, we may be able to offer some components for the development of such maps. Our position in the work in China has been to rely on a basic agreed-upon responsibilities framework (see Dewhurst and MacDowell 2015) (a common American strategy that we shared with 
our partners) in tandem with a broad formal agreement about intentions and mutual obligations. This was written in Mandarin and English and agreed upon in advance and signed in a public ceremony at the start of the collaboration (a common Chinese strategy shared by our partners and one essential in the Chinese administrative context). It may be that a set of road maps, even if diverse, would be too prescriptive to address all collaborative contexts in which museum ethnography is pursued. A case can be made for partners needing to invest in one another in an open-ended way, so as to gain trust and mutual understanding on which more elaborate work can be pursued. I refer to this article, as in the abstract and opening passages, as a reflective work. By that, I mean that it is born out of reflecting, on an institutional plane, on institutional collaborations of which $I$, as the director of the Mathers Museum, have be a part. As noted by a Museum Anthropology peerreviewer, it is not a reflection in the more personal, subjective sense. It was written for an occasion on which a group of university-based anthropology museum directors recounted recent museum projects and sought to generalize lessons from that work. Readers seeking more personal reflections related to the collaborations linking individuals and institutions in China and the United States, can find a book-length collection of personal experience narratives 
reflecting on this collaborative work in a book edited by $\mathrm{zhang}$ and Song (2017). More biographical reflections on the our work with Chinese partners and in Indiana may be something that I, or my colleagues in these efforts, pursue in the future. 

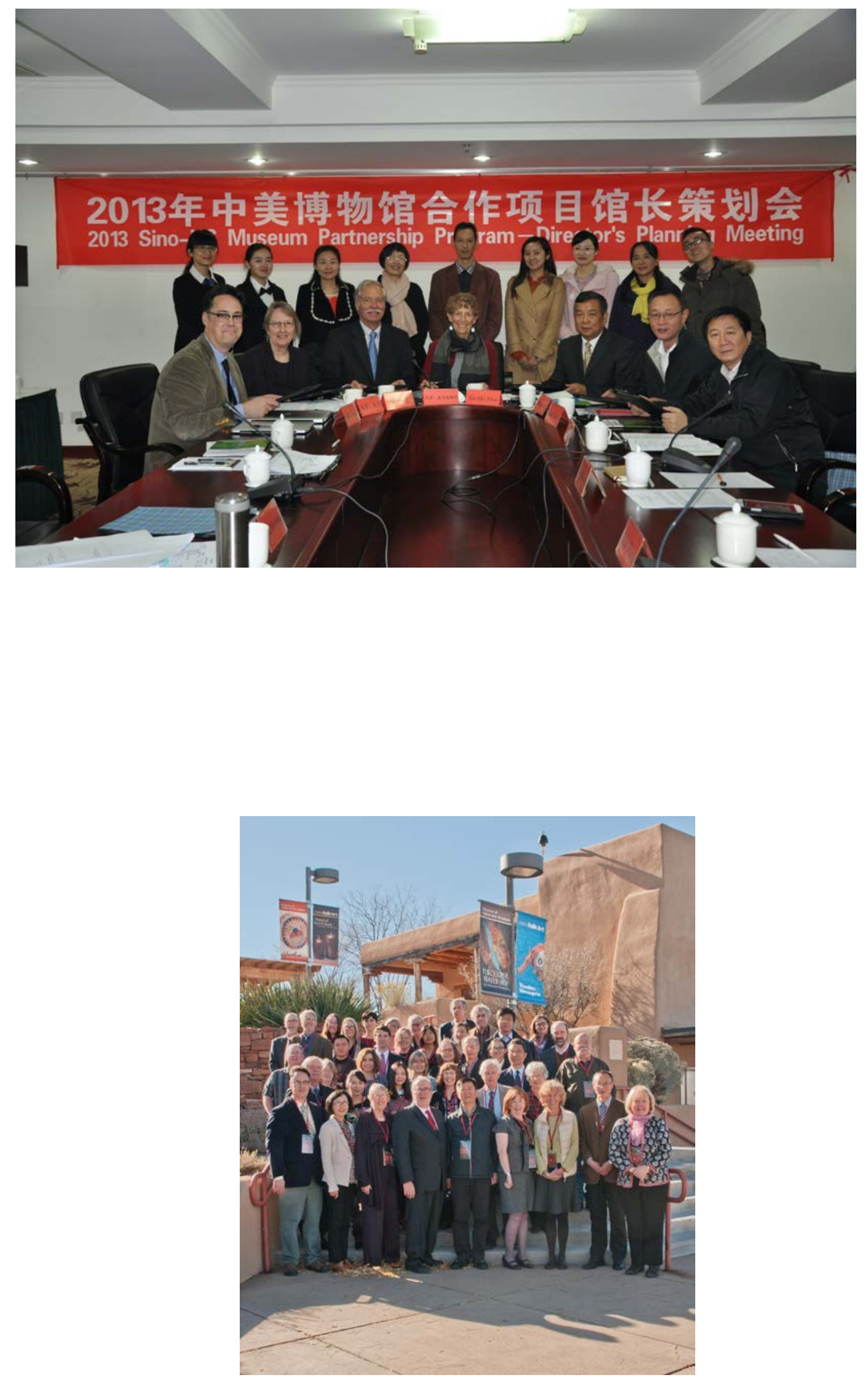

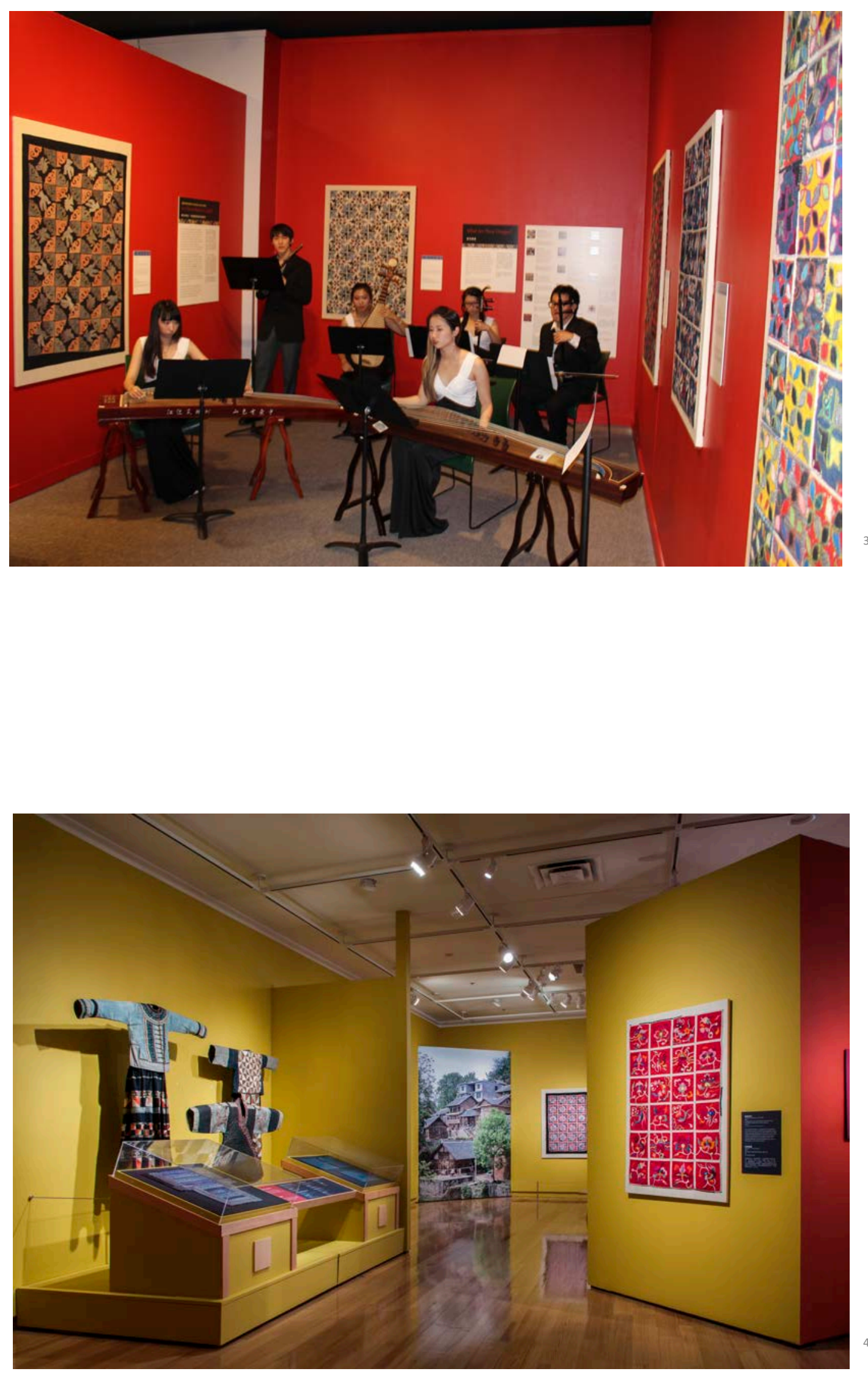

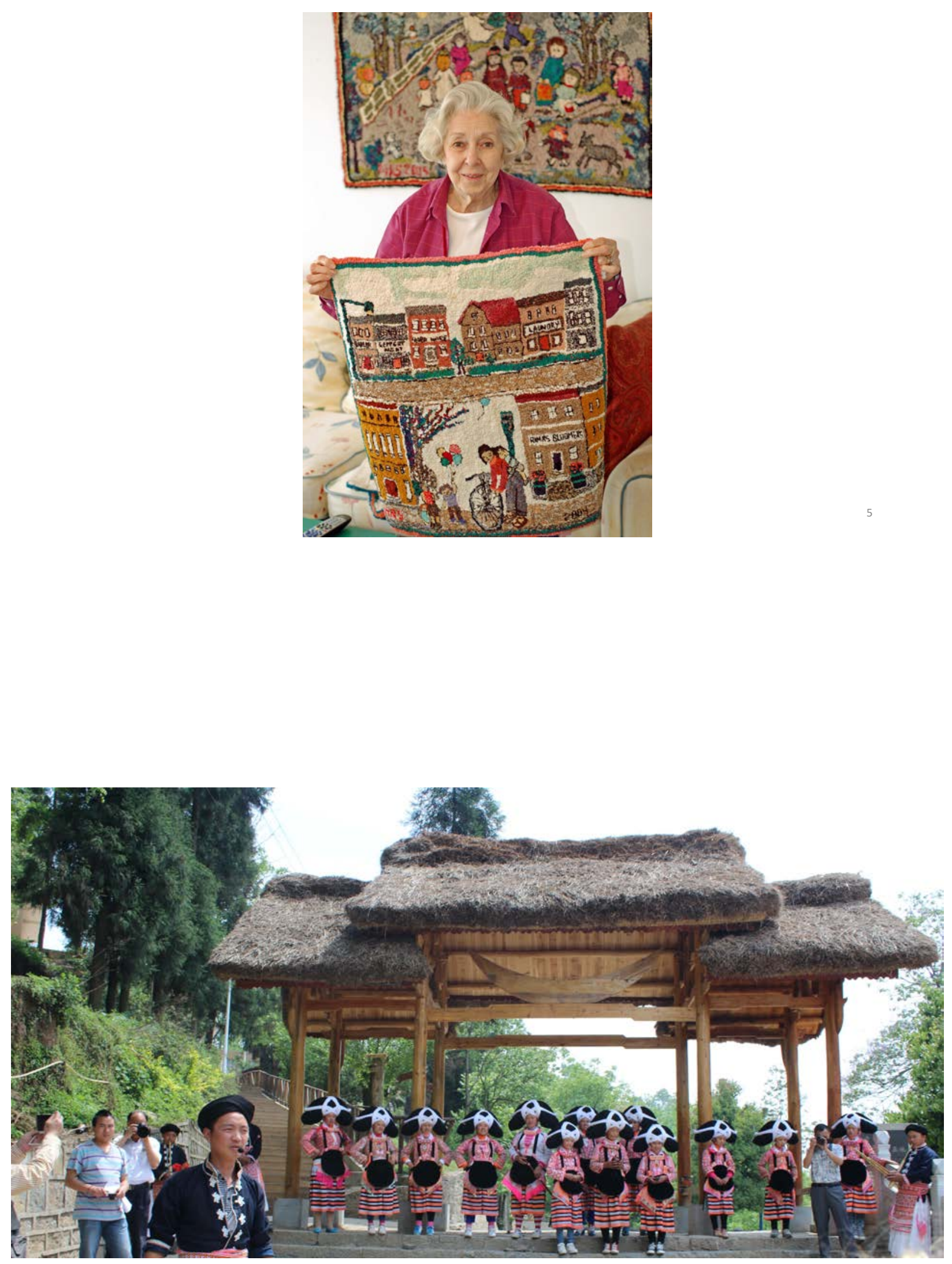

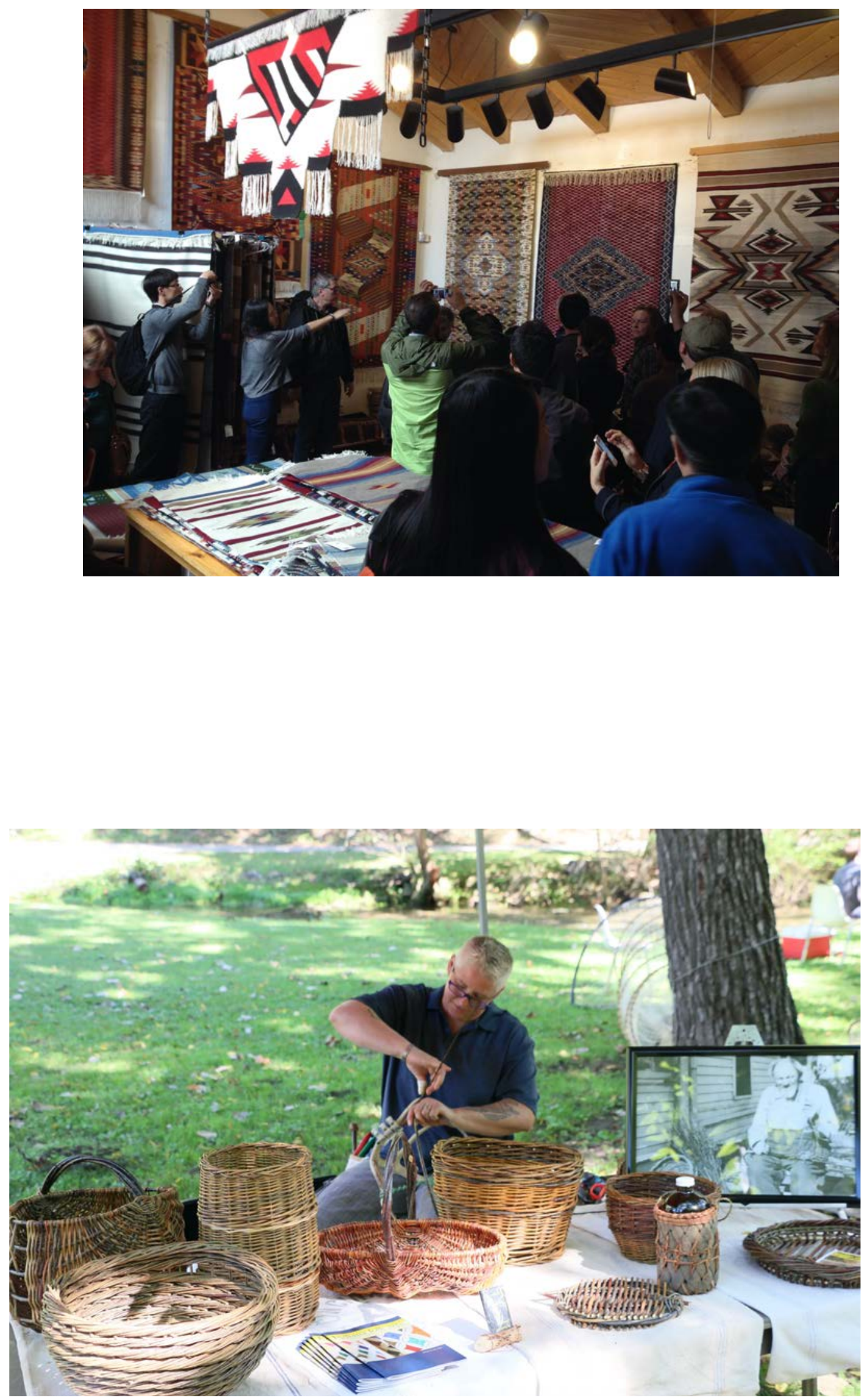

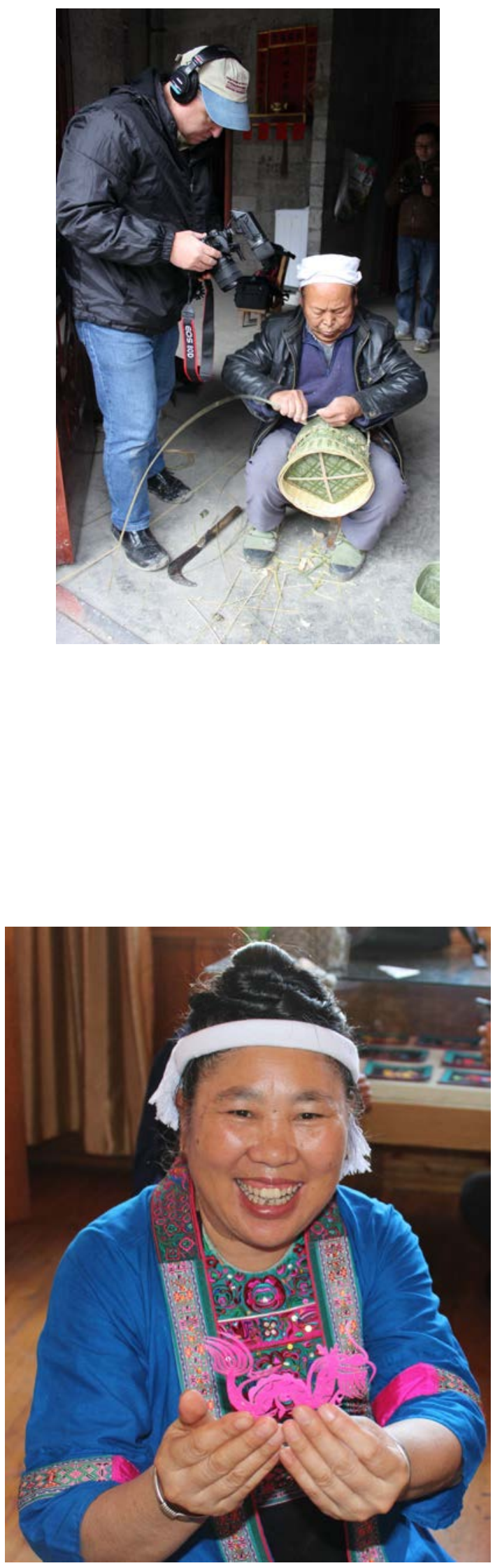